\title{
Analysis of Clinical Manifestations of Acute and Chronic Brucellosis in Patients Admitted to a Public General Hospital in Northern China
}

\author{
Chang-Min Liu' ${ }^{1} *$ \\ Bing Suo ${ }^{2, *}$ \\ Yan Zhang ${ }^{3, *}$
}

'General Hospital of Heilongjiang Province Land Reclamation Bureau Infectious Disease Department, Harbin, I50088, People's Republic of China;

${ }^{2}$ General Hospital of Heilongjiang

Province Land Reclamation Bureau Scientific Research Section, Harbin, I50088, People's Republic of China; ${ }^{3}$ General Hospital of Heilongjiang Province Land Reclamation Bureau Clinical Laboratory, Harbin, I50088, People's Republic of China

*These authors contributed equally to this work
Correspondence: Yan Zhang

General Hospital of Heilongjiang Province Land Reclamation Bureau Clinical Laboratory, No. 235, Hasuang Road, Nangang District, Harbin, Heilongjiang Province, 150088, People's Republic of China

Tel $+8645 I-55197654$

Fax +86 45I-55I97854

Email zhangyanhhn@163.com
Objective: To analyze the clinical features of patients with acute and chronic brucellosis in order to further improve the understanding of the disease.

Methods: The clinical data of 144 patients with brucellosis who were admitted to our hospital were selected for retrospective analysis and were divided into two groups: the acute phase group $(n=86)$ and the chronic phase group $(n=58)$, and the clinical characteristics of the acute and chronic phases of the disease were analyzed. The $\chi^{2}$ test was used for countable data comparisons between the two groups.

Results: Brucella melitensis was found as the contact organism in 61 patients $(70.93 \%)$ in the acute phase group and in 12 patients $(20.69 \%)$ in the chronic phase group $(\mathrm{p}<0.01)$. Brucella abortus was found as the contact organism in 14 patients $(16.28 \%)$ in the acute phase group and in 38 patients $(65.52 \%)$ in the chronic phase group $(\mathrm{p}<0.01)$. The results showed that the respective prevalence of fever, excessive sweating, splenomegaly, and lymph node enlargement were higher in the acute phase group than in the chronic phase group $(\mathrm{p}<$ $0.01)$. The respective prevalence of testicular swelling and pain were higher in the acute phase group than in the chronic phase group $(\mathrm{p}<0.05)$, while the prevalence of joint and muscle pain was higher in the chronic phase group than in the acute phase group $(\mathrm{p}<0.01)$.

Conclusion: In Harbin, two types of clinical brucellosis, acute and chronic phase, infected sheep and cattle, respectively, are endemic at the same time, which complicates diagnosis. Besides, the clinical manifestations of brucellosis are complex and diverse, and they are often misdiagnosed and mistreated, leading to serious health injuries. Therefore, it is important to improve the understanding of disease characteristics in patients with acute and chronic brucellosis.

Keywords: brucellosis, clinical characteristics, acute phase, chronic phase

\section{Introduction}

Brucellosis is a common zoonotic, infectious disease caused by Brucella, ${ }^{1-3}$ which can induce infection in humans and a variety of animals. ${ }^{4}$ Its clinical manifestations include fever, excessive sweating, malaise, and arthralgia as well as liver, spleen, and lymph node enlargement. The human immune system could be affected by the brucellosis and could cause acute, sub-acute and chronic clinical features. ${ }^{5}$ In some cases, the acute brucellosis showed with fever, fatigue, chills and sweating. Besides, it has been reported that sacroiliitis and polyarthritis were more frequent complications in acute cases and spondylitis mainly occurred in the patients with sub-acute and chronic disease. ${ }^{5,6}$ There are approximately 500,000 new brucellosis cases identified worldwide annually. ${ }^{7,8}$ 
It is a systemic disease with complex and diverse clinical manifestations. ${ }^{9}$ Brucella is a small, Gram-negative bacterium that is intracellularly parasitic, with a high invasion ability and a wide infection route. It is either spherical or short and rod-shaped in form. Brucella has complex interactions with the immune system of the host after entry, such as killing by professional phagocytes. It inhibits the immune system from killing the bacteria, thus facilitating their survival and reproduction in the host cells. ${ }^{10}$ In recent years, the national brucellosis epidemic has shown a rising year-byyear trend. ${ }^{11}$ Furthermore, the distribution area has expanded from infected to non-infected areas as well as from rural to urban areas. The brucellosis prevalence in China was initially concentrated in the Northeast and Inner Mongolia. Harbin, an important industrial city in northeast China, is located closely with the Brucella-endemic areas of northern China. Harbin is one of the epidemic areas with Today. ${ }^{12}$ The disease is transmitted to humans mainly by contact with infected animals, which is the main source of the infection. The most common animals carrying the infection are sheep, followed by cows and pigs. The route of the pathogenic bacteria infection leads primarily through the digestive tract and can be contracted via skin mucosa and respiratory transmission. However, human-to-human transmission is rare. ${ }^{13}$ Due to the complex and diverse clinical manifestations of the disease, misdiagnosis and missed diagnosis often occur, causing serious injury to patient health. To further deepen the understanding of this disease, the clinical data of 144 patients with brucellosis who were admitted to our hospital were retrospectively analyzed and summarized.

\section{Materials and Methods}

\section{Study Subjects}

A total of 144 patients with brucellosis were admitted to the Infection Department of the General Hospital of Heilongiiang Agricultural Reclamation Bureau between January 1, 2020, and September 31, 2020. These patients were enrolled in the present study. The inclusion criteria were as follows: (1) patients with complete clinical data; (2) patients with a positive brucellosis serological test result; (3) patients with a test tube agglutination test result of $\geq 1: 100^{++}$; and (4) patients with a positive rose bengal plate test (RBPT) result. ${ }^{14}$ The diagnoses were made in line with the People's Republic of China health industrystandard WS269-2007 "Diagnostic Criteria for Brucellosis."

\section{Methods}

A total of 144 patients with brucellosis were clinically staged according to WS269-2007 "Diagnostic Criteria for Brucellosis" based on the patient history collection findings.

The general patient characteristics, including age, gender, occupation, epidemiological exposure history, and clinical manifestations, were compared between the acute phase group and the chronic phase group. According to the diagnostic criteria for brucellosis (WS269-2019) - The health industry standard of the people's Republic of China: the course of disease within 6 months belongs to acute and chronic more than 6 months.

Serological tests: The diagnosis of brucellosis was based on the RBPT and the standard tube agglutination test (SAT), which are described previously. ${ }^{14}$ A titre of $1: \geq 100++$ was considered positive. The threshold titer for diagnosis of Brucella is more than 1/160. Similarly, chronic Brucella is defined as more than 1 year. The antigens used in the above tests were prepared at the Institute of Infectious Disease of the China Centers for Disease Control and Prevention.

Pathogen isolation and identification: The blood samples were obtained from the patients between January 2020 and September 2020. Conventional biological methods were used for the isolation and identification of the bacteria. ${ }^{15}$

The Statistical Package for Social Sciences 16.0 software was adopted for data analysis, and the $\chi^{2}$ test was used for the evaluation of countable data. Wilcoxon rank sum test was used to compare the age between acute and chronic phase groups. $P$ value of $<0.05$ was considered statistically significant.

\section{Results}

\section{General Characteristic Comparison Between the Two Patient Groups}

A toll of 144 showed the presence of antibodies against Brucella antigen by RBPT and SAT. The general characteristics of patients in the acute phase group were as follows: the group comprised 86 patients (64 males and 22 females) aged 4-65, with an average age of 35.5 years. Among these patients, there were 47 farmers, 23 herders, 7 veterinarians, 5 regular citizens, and 4 children. The age between the two groups was no significant difference $(P=0.216)$. The disease durations were 1-5 months, with an average duration of 3 months. Before the disease onset, 61 patients (70.93\%) 
came into contact with infected sheep and 14 patients $(16.28 \%)$ with infected cows. In 6 patients, the contact animal type was unclear. The remaining 5 patients were regular citizens, 3 of 5 had a history of drinking uncooked milk and 2 of 5 had a history of eating mutton.

The general patient characteristics in the chronic phase group were as follows: the group comprised 58 patients (44 males and 14 females) aged 18-76, with an average age of 39.5 years. Among these patients, there were 37 farmers, 13 herders and dairy workers, 6 citizens, and 2 veterinarians. The disease durations were 6-24 months, with an average duration of 8 months. Before the disease onset, 38 patients (65.52\%) came into contact with a diseased cow and 12 patients $(20.69 \%)$ came into contact with a diseased sheep. In 4 patients, the contact animal type was unclear, and the remaining 4 cases had a history of consuming beef or mutton.

In the general characteristic comparison between the two groups, the male-to-female ratio was 3-4:1; there was no statistically significant difference in the male-to-female ratios between the two groups. In terms of disease onset, patients in the acute phase group had a relatively lower age than the patients in the chronic group; the acute phase group even comprised pediatric patients (Table 1).

\section{Contact Organism Type Comparison Between the Two Groups}

Brucella melitensis (i.e., patients only had contact with an infected sheep before the disease onset) was found as the

Table I Comparison of Age Between Acute and Chronic Groups

\begin{tabular}{|l|l|l|l|}
\hline $\begin{array}{l}\text { Age } \\
\text { (Years) }\end{array}$ & $\begin{array}{l}\text { Acute Phase } \\
\text { Group (\%) }\end{array}$ & $\begin{array}{l}\text { Chronic Phase } \\
\text { Group (\%) }\end{array}$ & P-value \\
\hline $0-17$ & $4(4.65 \%)$ & 0 & 0.216 \\
$18-44$ & $23(26.74 \%)$ & $19(32.76 \%)$ & \\
$45-59$ & $35(40.70 \%)$ & $28(48.28 \%)$ & \\
$60-74$ & $24(27.91 \%)$ & $11(18.97 \%)$ & \\
Total & 86 & 58 & \\
\hline
\end{tabular}

contact organism in 61 patients $(70.93 \%)$ in the acute phase group and in 12 patients $(20.69 \%)$ in the chronic phase group; the difference between the two groups was statistically significant $(\mathrm{p}<0.01)$. Furthermore, Brucella abortus (i.e., patients only had contact with an infected cow before the disease onset) was found as the contact organism in 14 patients $(16.28 \%)$ in the acute phase group and in 38 patients $(65.52 \%)$ in the chronic phase group; the difference between the two groups was statistically significant $(\mathrm{p}<0.01)$ (Table 2). The odds ratio for the relationship between species and acute/chronic manifestation was 13.80 .

\section{Main Clinical Characteristic Comparison Between the Two Groups}

The clinical disease manifestations were compared between the two groups. The respective prevalence of fever, excessive sweating, splenomegaly, and lymph node enlargement were higher in the acute phase group than in the chronic phase group $(\mathrm{p}<0.01)$. The prevalence of testicular swelling and pain were higher in the acute phase group than in the chronic phase group $(\mathrm{p}<0.05)$, while the prevalence of joint and muscle pain was higher in the chronic phase group than in the acute phase group $(\mathrm{p}<0.01)$. There were no differences in the prevalence of weakness and liver enlargement between the two groups $(\mathrm{p}>0.05)$ (Table 3$)$.

\section{Discussion}

Brucellosis prevalence is higher in men than in women due to its occupational factor. ${ }^{16}$ When comparing the general characteristics between the acute phase group and the chronic phase group, the male-to-female ratios were approximately 3-4:1 in both, with no significant difference between the two groups. The infection rate was higher in young adults, of whom the workforce mainly consists and who frequently come into contact with infected animals, than in other age groups $(P>0.5)$. The primary patient occupation was farming, with $47(54.65 \%)$ in the acute phase group and $37(63.79 \%)$ cases in the chronic phase group. Both patient groups comprised citizens, who were

Table 2 Comparison of Biological Types of Contact Infection Between Acute Stage and Chronic Stage

\begin{tabular}{|l|l|l|l|l|l|}
\hline Group & Num. & Sheep & Cows & Both Sheep and Cows & Other \\
\hline Acute Phase & 86 & 61 & 14 & 6 & 5 \\
Chronic Phase & 58 & 12 & 38 & 4 & 4 \\
$\chi^{2}$ & & 34.98 & 36.4 & 0 & 0.069 \\
$P$ & & $P<0.01$ & $P<0.01$ & $P>0.05$ & $P>0.05$ \\
\hline
\end{tabular}


Table 3 Comparison of Main Clinical Manifestations Between the Acute Phase and Chronic Phase

\begin{tabular}{|c|c|c|c|c|c|c|c|c|c|}
\hline \multirow[t]{2}{*}{ Group } & \multirow{2}{*}{$\begin{array}{l}\text { Num. } \\
\text { (\%) }\end{array}$} & \multicolumn{8}{|c|}{ Number of Clinical Symptoms } \\
\hline & & Fever & Weakness & $\begin{array}{l}\text { Excessive } \\
\text { Sweating }\end{array}$ & $\begin{array}{l}\text { Joint and } \\
\text { Muscle } \\
\text { Pain }\end{array}$ & $\begin{array}{l}\text { Testicular } \\
\text { Swelling and } \\
\text { Pain }\end{array}$ & $\begin{array}{l}\text { Liver } \\
\text { Enlargement }\end{array}$ & Splenomegaly & $\begin{array}{l}\text { Lymph } \\
\text { Node } \\
\text { Enlargement }\end{array}$ \\
\hline $\begin{array}{l}\text { Acute } \\
\text { phase }\end{array}$ & $86(\%)$ & $\begin{array}{l}65 \\
75.58\end{array}$ & $\begin{array}{l}71 \\
82.56\end{array}$ & $\begin{array}{l}52 \\
60.47\end{array}$ & $\begin{array}{l}55 \\
63.95\end{array}$ & $\begin{array}{l}13 \\
15.12\end{array}$ & $\begin{array}{l}16 \\
18.61\end{array}$ & $\begin{array}{l}31 \\
36.05\end{array}$ & $\begin{array}{l}42 \\
48.84\end{array}$ \\
\hline $\begin{array}{l}\text { Chronic } \\
\text { phase }\end{array}$ & $58(\%)$ & $\begin{array}{l}12 \\
20.69\end{array}$ & $\begin{array}{l}48 \\
82.76\end{array}$ & $\begin{array}{l}21 \\
36.21\end{array}$ & $\begin{array}{l}51 \\
87.93\end{array}$ & $\begin{array}{l}3 \\
5.17\end{array}$ & $\begin{array}{l}7 \\
12.07\end{array}$ & $\begin{array}{l}9 \\
15.52\end{array}$ & $\begin{array}{l}12 \\
20.69\end{array}$ \\
\hline $\begin{array}{l}X^{2} \\
P\end{array}$ & & $\begin{array}{l}42.63 \\
P<0.01\end{array}$ & $\begin{array}{l}0.001 \\
P>0.05\end{array}$ & $\begin{array}{l}8.24 \\
P<0.01\end{array}$ & $\begin{array}{l}10.99 \\
P<0.01\end{array}$ & $\begin{array}{l}3.72 \\
P<0.05\end{array}$ & $\begin{array}{l}2.09 \\
P>0.05\end{array}$ & $\begin{array}{l}7.48 \\
P<0.01\end{array}$ & $\begin{array}{l}11.92 \\
<0.01\end{array}$ \\
\hline
\end{tabular}

mainly infected through the consumption of unquarantined beef and mutton. ${ }^{17}$ In addition, contact with Brucellacontaminated sheep and cows, or their secretions and hides as well as children playing with lambs or sucking on contaminated tests can lead to disease onset. As winter is cold in North China, lambs are often born inside houses, providing an opportunity for the children to be infected through close contact. In the acute phase group, 4 pediatric patients were infected when playing with lambs.

The Brucella genus is composed of 10 recognized species: Brucella melitensis, Brucella abortus, Brucella suis, Brucella ovis, Brucella canis, Brucella ovis, Brucella neotomae, Brucella ceti, Brucella pinnipediae, Brucella microti, Brucella inopinata. Of these, Brucella melitensis, Brucella abortus, and Brucella suis are the most infectious to humans. ${ }^{18}$ Most brucellosis epidemics and outbreaks in China are caused by the Brucella melitensis infection. ${ }^{19}$ Most clinical cases are caused by Brucella melitensis type 3, followed by Brucella melitensis type 1, while the least cases are caused by Brucella melitensis type $2 .^{20-22}$ Clinical manifestations following Brucella infection of different strains vary slightly. In the present study, patients in the acute phase group were primarily $(70.93 \%)$ infected through contact with sheep, with an average disease duration of 3 months. In contrast, patients in the chronic phase group were primarily $(65.52 \%)$ infected through contact with cows, with an average disease duration of 8 months. It was found that patients in the acute phase group, who had mainly been exposed to Brucella melitensis, might have an acute disease onset and short disease duration, while those in the chronic phase group, who had mainly been exposed to Brucella abortus, might have a slow disease onset and a relatively long disease duration.

Brucella pathogenesis is complex. ${ }^{23}$ When a large number of pathogenic bacteria break through the lymphatic barrier and enter the bloodstream, they develop into bacteremia. $^{24}$ Over the course of the disease, a generalized proliferation of the reticuloendothelial system takes place, leading to neurological, hematological, genitourinary, immune, and motor system injuries. Therefore, the clinical manifestations are also complex and varied. Common signs and symptoms include wave or relaxation fever, excessive sweating, fatigue, and arthralgia as well as an enlarged liver and spleen lymph nodes. In the clinical manifestation comparison between the acute phase group and the chronic phase group, the prevalence of fever, excessive sweating, splenomegaly, and lymph node enlargement was significantly higher in the acute phase group than in the chronic phase group $(\mathrm{p}<$ 0.01 ), and the prevalence of testicular swelling and pain was significantly higher in the acute phase group than in the chronic phase group $(\mathrm{p}<0.05)$. However, the respective prevalence of joint and muscle pain were significantly higher in the chronic phase group than in the acute phase group ( $\mathrm{p}<0.01$ ), and there were no significant differences in the prevalence of fatigue and liver enlargement between the two groups $(\mathrm{p}>0.05)$.

Due to the complex nature of the disease manifestations, many symptoms are unspecific. Furthermore, clinicians do not yet know enough about the disease, and doctors often fail to make a timely and accurate diagnosis; thus, misdiagnosis and missed diagnosis often occur. For example, the acute phase of brucellosis is often misdiagnosed as upper respiratory tract infection, rheumatic fever, tuberculosis, typhoid paratyphoid fever, meningitis, orchitis, testicular tuberculosis, while the chronic phase of brucellosis is often misdiagnosed as rheumatism, rheumatoid arthritis, bone and joint tuberculosis, spondylitis. Therefore, it is especially important to strengthen the 
understanding of acute and chronic brucellosis clinical features.

\section{Conclusion}

It is especially important to strengthen the understanding of acute and chronic brucellosis clinical features. In this study, the complexity of two types of clinical brucellosis, acute and chronic phase, infected sheep and cattle, respectively, was investigated. The clinical manifestations could be observed which are complex and diverse.

\section{Ethics Approval and Consent to Participate}

This study was conducted in accordance with the declaration of Helsinki. This study was conducted with approval from the Ethics Committee of General Hospital of Heilongjiang Province Land Reclamation Bureau Clinical Laboratory. A written informed consent was obtained from all participants.

\section{Disclosure}

All authors have contributed significantly to the manuscript and declare that the work is original and has not been submitted or published elsewhere. None of the authors have any financial disclosure or conflicts of interest in this work.

\section{References}

1. Ahmed W, Zheng K, Liu ZF. Establishment of chronic infection: Brucella's stealth strategy. Front Cell Infect Microbiol. 2016;6:30. PMID: 27014640; PMCID: PMC4791395. doi:10.3389/ fcimb. 2016.00030

2. Atluri VL, Xavier MN, de Jong MF, den Hartigh AB, Tsolis RM. Interactions of the human pathogenic Brucella species with their hosts. Annu Rev Microbiol. 2011;65(1):523-541. PMID: 21939378. doi:10.1146/annurev-micro-090110-102905

3. Miranda RT, Gimeno AE, Rodriguez TF, de Arriba JJ, Olmo DG, Solera J. Acute cholecystitis caused by Brucella melitensis: case report and review. $J$ Infect. 2001;42(1):77-78. PMID: 11243761. doi:10.1053/jinf.2000.0757

4. Al-Ani FK, El-Qaderi S, Hailat NQ, Razziq R, Al-Darraji AM. Human and animal brucellosis in Jordan between 1996 and 1998: a study. Rev Sci Tech. 2004;23(3):831-840. PMID: 15861878. doi:10.20506/ rst.23.3.1528

5. Geyik MF, Gur A, Nas K, et al. Musculoskeletal involvement of brucellosis in different age groups: a study of 195 cases. Swiss Med Wkly. 2002;132(7-8):98-105.

6. Hasanjani Roushan MR, Ebrahimpour S, Moulana Z. Different clinical presentations of Brucellosis. Jundishapur J Microbiol. 2016;9(4): e33765. PMID: 27284398; PMCID: PMC4897599. doi:10.5812/ jjm.33765
7. Pappas G, Papadimitriou P, Akritidis N, Christou L, Tsianos EV. The new global map of human brucellosis. Lancet Infect Dis. 2006;6 (2):91-99. PMID: 16439329. doi:10.1016/S1473-3099(06)70382-6

8. Galińska EM, Zagórski J. Brucellosis in humans-etiology, diagnostics, clinical forms. Ann Agric Environ Med. 2013;20(2):233-238.

9. Yang WD, Yang F. To investigate the epidemiology of brucellosis, clinical and laboratory features. J Clin Med Lit. 2015;57(3):465.

10. Celli J, de Chastellier C, Franchini DM, Pizarro-Cerda J, Moreno E, Gorvel JP. Brucella evades macrophage killing via VirB-dependent sustained interactions with the endoplasmic reticulum. J Exp Med. 2003;198(4):545-556. doi:10.1084/jem.20030088

11. Wang DL, Li Y. Review and thinking on prevention and control strategies of brucellosis. Chin J Endemiol. 2015;34(5):313-314. Chinese.

12. Zhong Z, Yu S, Wang X, et al. Human brucellosis in the people's republic of China during 2005-2010. Int J Infect Dis. 2013;17(5): e289-e92. doi:10.1016/j.ijid.2012.12.030

13. Shen DX. Clinical characteristics and laboratory detection of brucellosis infection. Chin J Lab Med. 2012;35(1):8.

14. Alton GG, Jones LM, Angus RD, Verger JM. Techniques for the Brucella Laboratory. Paris: Institut National de la Recherche Agronomique; 1988.

15. Xiao DLGS, Wang DL, Wang JQ, et al. Brucellosis Control Manual. Beijing: Beijing People's Medical Publishing House; 2008:17-29.

16. Arribas JL, Navarro JF, Hernández MJ, et al. La brucelosis enun hospital terciario. Estudio epidemiológico retrospectivo de 166 casos [Brucellosis at a tertiary hospital. Retrospective epidemiologic study of 166 cases]. Enferm Infecc Microbiol Clin. 1989;7(3):126-130. Spanish. PMID: 2490679.

17. Machavarapu M, Poonati R, Mallepaddi PC, et al. Endemic brucellosis in Indian animal and human populations: a billion dollar issue. J Curr Trends Biotechnol Pharm. 2019;13:112-123.

18. Dong SB, Jiang H, Wang LP. Progress in research and practice of brucellosis surveillance in China. Chin J Epidemiol. 2019;40 (7):870-874.

19. Li FX. Practical Brucellosis. Harbin: Heilongjiang Science and Technology Press; 2010:86-87.

20. Liu ZG, Wang M, Li YX, Liu RH. Identifation methods of Brucella melitensis. Chin J Endemiol. 2017;36(9):653-656.

21. Tian GZ, Cui BY, Piao DR, et al. Multi-locus variable-number tandem repeat analysis of Chinese Brucella strains isolated from 1953 to 2013. Infect Dis Poverty. 2017;6(1):89. doi:10.1186/ s40249-017-0296-0

22. Liu ZG, Wang M, Liu RH, Shang XJ, Cui BY. HOOF genotyping characteristics of Brucella melitensis strains isolated in Ulanqab of Inner Mongolia Autonomous Region. Chin J Epidemiol. 2017;38 (7):954-958. Chinese.

23. Tupik JD, Coutermarsh-Ott SL, Benton AH, et al. ASC-mediated inflammation and pyroptosis attenuates Brucella abortus pathogenesis following the recognition of gDNA. Pathogens. 2020;9(12):1008. PMID: 33266295; PMCID: PMC7760712. doi:10.3390/ pathogens 9121008

24. Bannatyne RM, Jackson MC, Memish Z. Rapid diagnosis of Brucella bacteremia by using the BACTEC 9240 system. J Clin Microbiol. 1997;35(10):2673-2674. PMID: 9316932; PMCID: PMC230035. doi:10.1128/jcm.35.10.2673-2674.1997 


\section{Publish your work in this journal}

The International Journal of General Medicine is an international, peer-reviewed open-access journal that focuses on general and internal medicine, pathogenesis, epidemiology, diagnosis, monitoring and treatment protocols. The journal is characterized by the rapid reporting of reviews, original research and clinical studies across all disease areas. The manuscript management system is completely online and includes a very quick and fair peer-review system, which is all easy to use. Visit http://www.dovepress.com/ testimonials.php to read real quotes from published authors. 